УДК 621.317

DOI: https://doi.org/10.26642/ten-2021-1(87)-98-103

\author{
В.Б. Бенедицький, ст. викладач \\ О.Л. Коренівська, к.т.н., доц. \\ Д.С. Морозов, ст. викладач \\ Державний університет «Житомирська політехніка»
}

\title{
Визначення вологості зерна за тиском вологого повітря
}

\begin{abstract}
Стаття присвячена розгляду питання контролю за ступенем вологості зерна під час зберігання, транспортування та переробки. Актуальність теми обумовлена потребою експресконтролю вологості як одного зі иляхів підвищення якості, продуктивності та зниження витрат, у тому числі ц̌ енергетичних, під час підготовки, виробництва, переробки, транспортування й зберігання зерна та продуктів його переробки - круп, комбікормів, макаронів, хліба і хлібобулочних виробів. У роботі розглянуто ризики впливу вологості зерна на його якість, відомі методи вимірювання вологості зерна, описано їх переваги та недоліки. Показано, шзо шляхом удосконалення відомих методів можна збільшити точність вимірювання та чутливість. Досліджено залежність тиску вологого повітря від вологості зерна. Показано, щуо тиск вологого повітря залежить тільки від кількості води в одиниці об’єму зерна $i$ не залежить від його питомої ваги. Наведено емпіричні формули та методику теоретичного розрахунку вологості зерна по зміні тиску повітря в камері. Представлено результати експериментальних вимірювань, щчо підтверджують справедливість теоретичних розрахунків. На основі отриманих теоретичних результатів розроблена інженерна методика розрахунку маси води, шуо містить проба зерна, яка може використовуватися для проєктування реальних приладів. Запропоновано модельну структуру для оиінювання впливу розкиду визначальних параметрів на похибку вимірювання маси води, та наведено результати моделювання, отримані за допомогою середовища Місго-Сар. Поставлено завдання для подальших досліджень.
\end{abstract}

Ключові слова: вологість зерна; вологомір; тиск маси вологи; дистиляційний метод; похибка вимірювання.

Постановка проблеми у загальному вигляді та ії зв'язок 3 важливими практичними завданнями. Волога $\epsilon$ одним 3 основних компонентів більшості сільськогосподарських продуктів, що визначає їх якість [1-3]. Вологість зерна, бавовни та інших продуктів є основним чинником, від якого залежить можливість тривалого зберігання без псування і втрат цих матеріалів. Значення вологості характеризує та відображає кількість поживних речовин у зерні, а також його готовність до зберігання та подальшої обробки. Вологе зерно містить меншу кількість поживних речовин, а при тривалому зберіганні може змінюватися та псуватися. Наявність вологи активізує фізичні та фізіологічні процеси, які негативно впливають на його зберігання й переробку. Під час переробки зерна від його вологості залежать опір подрібненню, а отже, питома витрата енергії і продуктивність млинового устаткування. Величина вологості зерна враховується під час здачі й приймання, оскільки від неї залежать його чиста вага і дійсна вартість. Вимірювання вологості зерна потрібно проводити на різних стадіях його обробки.

В сучасних умовах необхідні універсальні пристрої для контролю вологості різних сільськогосподарських матеріалів без додаткового переналаштування з великою точністю вимірювання. Тому виникає потреба у розробці методу контролю, який гарантуватиме такі ж за точністю дані, як і прямий метод вимірювання вологості, та відповідатиме необхідним вимогам: визначення значення вологості зерна в потоці, а не в окремих його частинах; забезпечення зняття даних у реальному часі; абсолютна похибка вимірювань не має становити більше $\pm 1 \%$.

Методи визначення вологості зерна, бавовни та інших продуктів дуже різноманітні й не обмежуються методами, які передбачені стандартами [4]. Велика кількість різних методів постійно вивчається, удосконалюється і розглядається як основа для створення сучасних вимірювачів вологості, для контролю вологості у виробничому процесі. Всі методи визначення вологості зерна поділено на дві групи: прямі та непрямі. Прямі методи являють собою види лабораторного аналізу: хімічні (екстрагування вологи 3 проби досліджуваної речовини 3 подальшим визначенням вологості за діелектричною проникністю), вагові (сушка проби речовини до досягнення незмінної ваги), дистиляційні (відбір вологи потоком підсушеного газу). Непрямі методи засновані на залежності вологи від якості електричного сигналу. Характерні більшою продуктивністю й експресністю, що дозволяє створити системи автоматичного контролю. Існують різні електрофізичні методи визначення вологості зерна $[1,5]$ :

1) непрямі методи, засновані на визначенні температури, що залежить від вологості досліджуваного матеріалу;

2) методи, фізичною основою яких є:

() В.Б. Бенедицький, О.Л. Коренівська, Д.С. Морозов, 2021 
- інфрачервоне випромінювання;

- ядерно-магнітний резонанс;

- взаємодія ядерного випромінювання з речовиною;

- зміна амплітуди і фази пройденого через матеріал, що містить вологу, електромагнітного НВЧвипромінювання $[6,7]$;

- зміна амплітуди відбитого від волого матеріалу електромагнітного НВЧ-сигналу випромінювання.

Серед прямих методів, що забезпечують швидке і точне вимірювання вологості зерна, особливий інтерес становить дистиляційний метод або метод для прямого об'ємного визначення вмісту вологи, в основі якого лежить перегонка, випаровування рідини з наступним охолодженням та конденсація пару. Недоліком цього дистиляційного методу $є$ використання переважно вогненебезпечних розчинників та розріджувачів (допоміжних рідин), зазвичай з використанням скляної апаратури. Крім того, налипання водяних капель на внутрішніх поверхнях холодильника та вимірювання кількості води за допомогою мірного судна зменшує точність вимірювання [8].

Мета статті. Робота присвячена аналізу залежності тиску вологого повітря від вологості зерна та націлена на усунення розглянутих вище недоліків, що виникають під час вимірювання вологості дистиляційним методом.

Викладення основного матеріалу дослідження. Представимо зерно масою $m$ як систему, що складається 3 двох складових: сухої речовини масою $m_{1}$ і води масою $m_{2}$, тобто $m=m_{1}+m_{2}$. Зразок зерна масою $m$ розмістимо в герметично закриту місткість об'ємом $V$. Закрита місткість нагрівається до температури $T$. Вода, що міститься в зразку зерна, переходить зі зв'язаного стану у водяну пару та 3 сухим повітрям, до початку нагріву, утворює вологе повітря. Оскільки система закрита, то всередині змінюється тиск. Визначимо зміну тиску $P$ під час нагріву зразків до температури $T$, щоб визначити чи буде зміна тиску пов'язана 3 масою води $m_{2}$. Вважатимемо, що початкові умови нормальні: $P_{0}, T_{0}$.

Відомо, що за законом Дальтона тиск [9]:

$$
P=P_{1}+P_{2},
$$

де $P_{1}$ - тиск сухого повітря; $P_{2}$ - тиск водяної пари.

Оскільки нагрівання проходить при постійному об'ємі $V$, то тиск сухого повітря $P_{1}$ за температури $T$ визначається за законом Шарля [9]:

$$
\frac{P_{0}}{T_{0}}=\frac{P_{1}}{T} .
$$

3 виразу (2) одержуємо:

$$
P_{1}=\frac{P_{0} T}{T_{0}} .
$$

Знайдемо тиск водяної пари вважаючи іï ідеальним газом. Кількість молей водяної пари у місткості визначається таким виразом:

$$
n=\frac{m_{2}}{\mu},
$$

де $\mu$ - молярна маса водяної пари.

За нормальних умов водяна пара масою $m_{2}$ займає об’єм $V^{*}$ :

$$
V^{*}=V_{0} n \text {, }
$$

де $V_{0}$ - об'єм одного моля довільного газу за нормальних умов.

3 виразів (4) і (5) одержуємо:

$$
V^{*}=V_{0} \frac{m_{2}}{\mu} \text {. }
$$

Згідно із законом газового стану:

$$
\frac{P_{0} V^{*}}{T_{0}}=\frac{P_{2} V}{T},
$$

тоді 3 (7) одержуємо тиск $P_{2}$ водяної пари:

$$
P_{2}=\frac{P_{0} V^{*} T}{T_{0} V},
$$

з урахуванням (6) маємо:

$$
P_{2}=\frac{P_{0} V_{0} T m_{2}}{T_{0} V \mu} .
$$

Вирази (3) і (9) свідчать, що тиск $P$ вологого повітря:

$$
P=\frac{P_{0} T}{T_{0}}+\frac{P_{0} V_{0} T m_{2}}{T_{0} V \mu}=\frac{P_{0} T}{T_{0}}\left(1+\frac{V_{0} m_{2}}{V \mu}\right) .
$$


Таким чином, з виразу (10) бачимо, що тиск $P$ лінійно пов'язаний з масою води $m_{2}$ i температурою нагріву $T$. Визначимо умову, за якої тиск від водяної пари буде перевищувати тиск сухого повітря:

$$
P_{2} \gg P_{1} \text {. }
$$

Підставивши (9) та (3) в (11) після перетворення нерівності маємо:

$$
\frac{V_{0} m_{2}}{\mu} \gg V \text {. }
$$

3 виразу (12) одержуємо, що виконання умови (11) залежить від об’єму $V$ герметично закритої посудини і маси води $m_{2}$.

Таким чином, за виконання умови (11), визначення вологості зерна пов'язане зі знаходженням тиску $P$, що утворився в герметично закритій посудині об'ємом $V$ та при температурі нагріву $T$.

Визначимо, який потрібно обирати об’єм закритої посудини $V$ залежно від маси води $m_{2}$. Припустимо, що маса проби зерна $m=20$ г, як при використанні повітряно-теплового методу без попереднього підсушування. Межі вологості зерна обираємо (8-25) \%. Маса води, що містить проба зерна $m_{2}=(1,6-5,0)$ г. Значення $V_{0}=22,41 \cdot 10^{-3} \mathrm{M} /$ моль,$\mu=18$ г/моль [9].

Отримані за теоретичним розрахунком результати графічно наведені на рисунку 1. Аналіз даних дозволяє зробити такі висновки:

- $\quad$ при $m_{2}=(1,6-5,0)$ г необхідно, щоб об'єм закритої посудини $V$ обирався в межах менше (2-6) л, але для точного виконання умови (11), при різних значеннях $m_{2}$, необхідно обирати об'єм $V<2$ л.

Таким чином, вибір об’єму $V$ визначає нижній край межі вимірювання кількості води в пробі.

Визначимо межі зміни тиску $P$ при нагріванні до температури $T$, при фіксованих значеннях маси вологи $m_{2}$ та об'єму посудини $V$ з виразу (10). Обираємо $V=0,5 \cdot 10^{-3} \mathrm{~m}^{3}$, температуру змінюємо в межах від $293,15 \mathrm{~K}\left(20^{\circ} \mathrm{C}\right)$ до $473,15 \mathrm{~K}\left(200^{\circ} \mathrm{C}\right), m_{2}=(1-6)$ г. Графічне зображення отриманих даних представлено на рисунку 2.

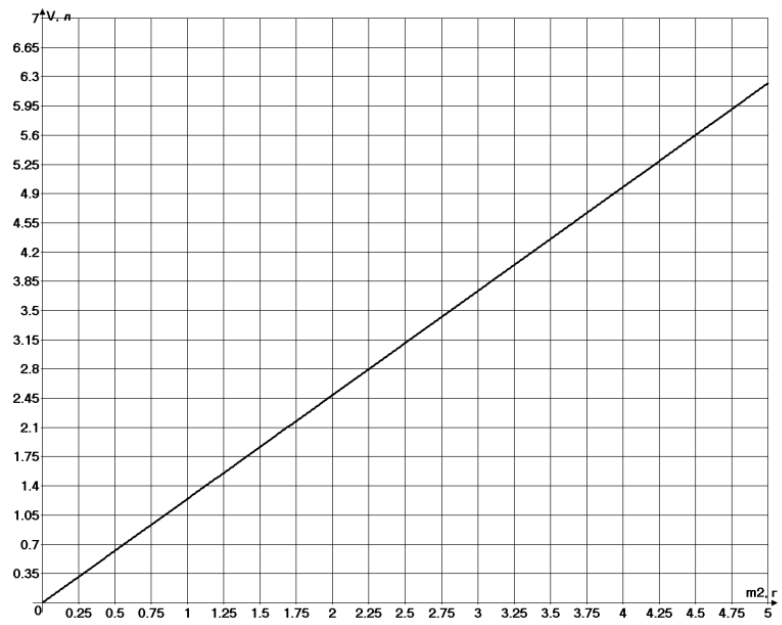

Рис. 1. Залежність об’єму закритої посудини V від маси води $m_{2}$

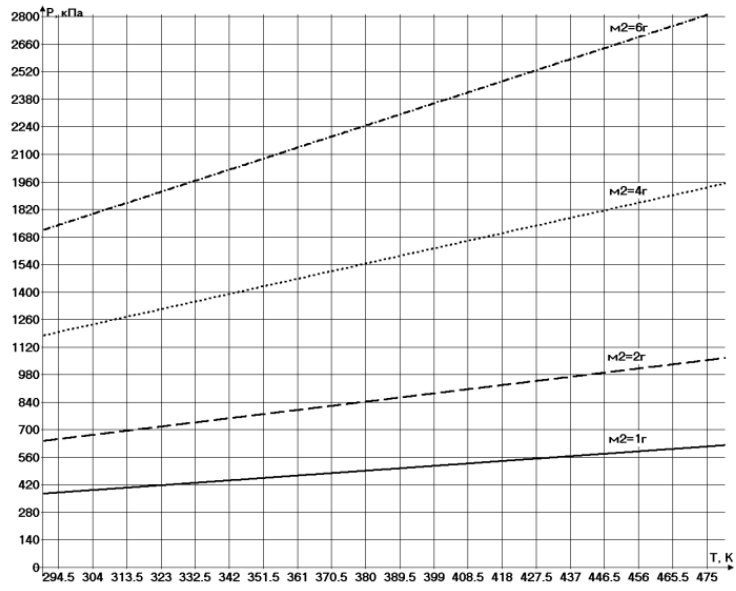

Рис. 2. Залежність зміни тиску $P$ під час нагріву до температури $T$ при фіксованих значеннях $m_{2} i V$ 
Аналіз цих графіків дозволяє зробити такі висновки:

- $\quad$ при підвищенні температури на $\Delta T=180 K$ тиск змінюється на $\Delta P=194$ кПа для $m_{2}=1 \Gamma$, для $m_{2}=2$ г тиск змінюється на $\Delta P=331$ кПа;

- $\quad$ при підвищенні температури тиск вологого повітря суттєво змінюється для $m_{2}=1$ г;

- $\quad$ тиск збільшуються в 1,73 раза при збільшенні кількості води в пробі на 1 г.

Алгоритм знаходження маси води, що містить проба зерна, визначається виразом:

$$
m_{2}=\frac{P_{0} T}{T_{0}}+\frac{P_{0} V_{0} T m_{2}}{T_{0} V \mu}=\frac{V_{0}}{V \mu}\left(\frac{T_{0} P}{T P_{0}}-1\right) .
$$

Як бачимо, визначальними параметрами алгоритму є тиск водяного пару $P$ та температура нагріву зразка $T$.

Виконаємо моделювання для оцінювання впливу розкиду визначальних параметрів на похибку вимірювання маси води. Моделювання будемо проводити в середовищі Micro-Сар [10], оскільки в ньому вже $€$ необхідні елементи для моделювання. Будемо використовувати функціональну схему, що представлена на рисунку 3. Схема містить такі блоки:

Блок 1 - формувач тиску водяного пару.

Блок 2 - формувач температури нагріву.

Блок 3 - формувач температури повітря 273,15 К.

Блоки 4 - формувач атмосферного тиску 101325 Па.

Блоки 5, 6, 12 - подільник.

Блоки 7, 13 - помножувач.

Блок 8 - суматор.

Блок 9 - формувач константи - 1 .

Блок 10 - формувач об'єму закритої посудини.

Блок 11 - формувач об'єму одного моля ідеального газу 22,41 · $10^{-3}$ м/моль

Блок 14 - підсилювач із коефіцієнтом $\mu=18$ г/моль

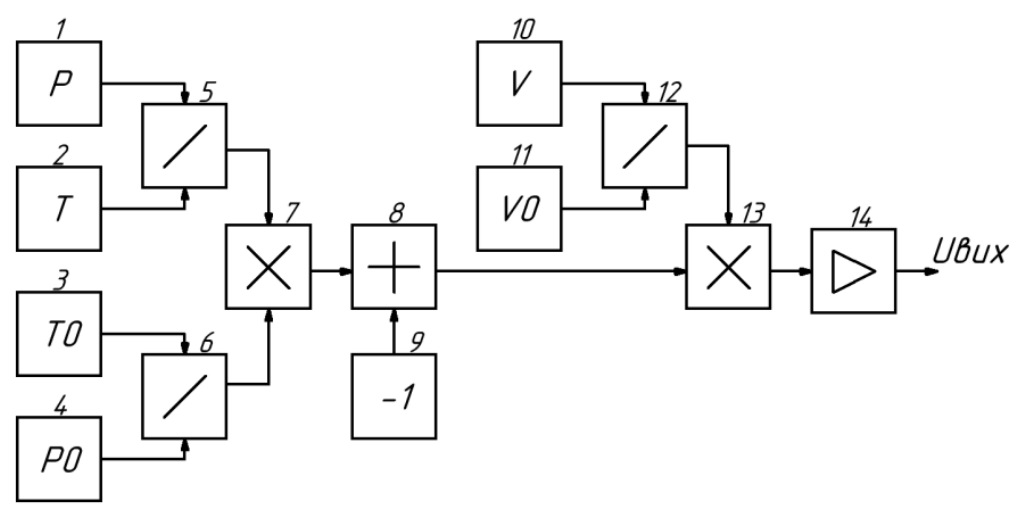

Рис. 3. Функціональна схема алгоритму знаходження маси води

За цією схемою побудуємо комп’ютерну модель в середовищі Місrо-Сар. Вихідна модель показана на рисунку 4.

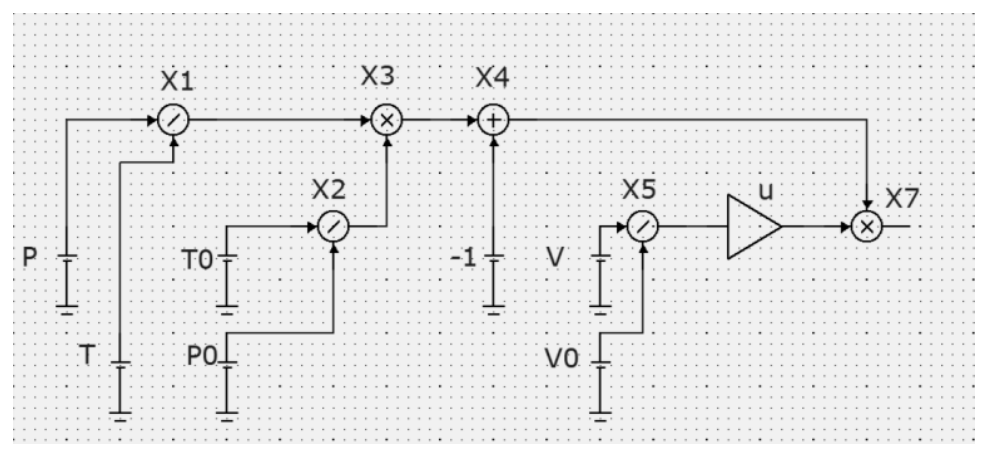

Рис. 4. Комп 'ютерна модель алгоритму знаходження маси води в середовищі Міско-Сар 
Розглянемо контрольний приклад за умови, що тиск водяного пару $P=1049579,7$ Па, температура нагріву $T=473,15$ К $є$ сталими, то результат моделювання $m_{2}=2$ г.

Розглянемо випадок, коли визначальні параметри встановлюються із помилкою $\pm 5 \%$.

В результаті моделювання отримали гістограму та закон розподілу похибки вимірювання маси води (рис. 5).

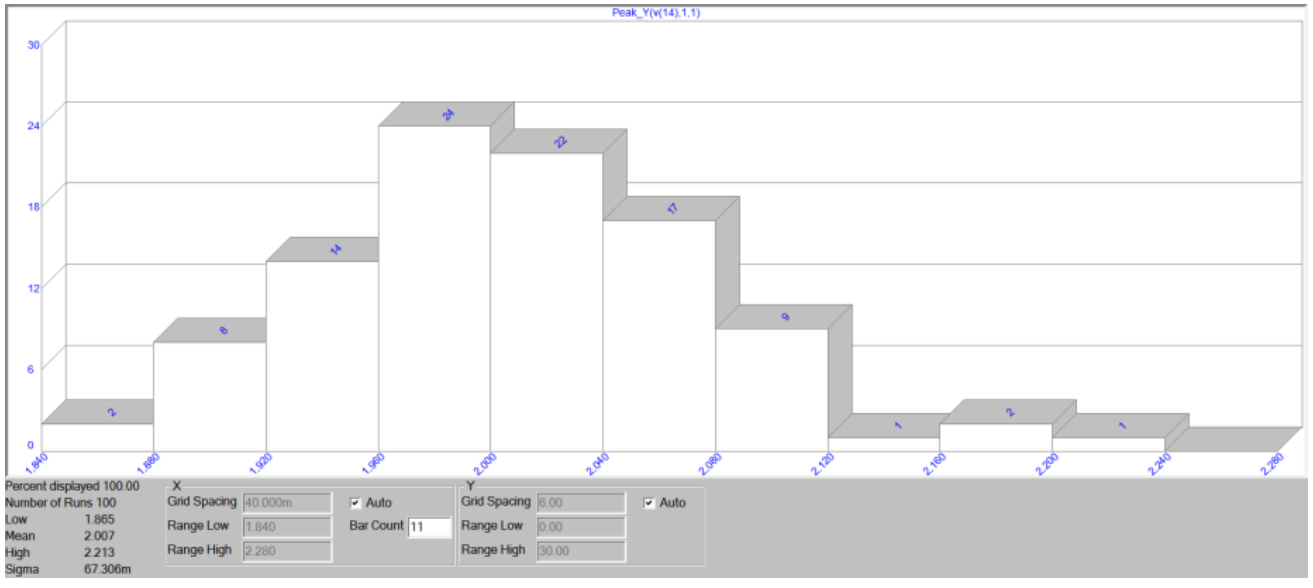

Рис. 5. Розподіл маси води за результатами моделювання

Параметри закону розподілу, що отримані в результаті моделювання: математичне очікування $M\left(m_{2}\right)=2,007$ г, середньо квадратичне відхилення $\sigma\left(m_{2}\right)=67,306 \cdot 10^{-3}$.

Висновки. В роботі досліджено теоретичну залежність тиску вологого повітря від вологості зерна. Описано методику вимірювання вологості зерна через термодинамічні характеристики тиску повітря та температури нагріву зерна (P, T) й аналітичні співвідношення (10)-(12). Показано, що тиск вологого повітря залежить тільки від кількості води в одиниці об’єму зерна і не залежить від питомої ваги зерна. Також дано рекомендації щодо вибору достатнього об'єму проби зерна, яка забезпечить необхідну точність вимірювання. Проведено оцінку впливу параметрів на похибку визначення вологості зерна. Параметри закону розподілу, що отримані в результаті моделювання: математичне очікування $M\left(m_{2}\right)=2,007$ г, середньо квадратичне відхилення $\sigma\left(m_{2}\right)=67,306 \cdot 10^{-3}$.

Метою подальших досліджень слід вважати оцінювання ефективності розробленої методики щодо точності та однозначності отриманих у результаті iї використання даних. А також розробка приладу вимірювання, що буде реалізовувати запропоновану методику вимірювання.

\section{Список використаної літератури:}

1. Лисовский В.В. Теория и практика сверхвысокочастотного контроля влажности сельскохозяйственных материалов / В.В. Лисовский. - Минск : БГАТУ, 2005. - 292 с.

2. Подпрятов Г.I. Технологія зберігання і переробки продукції рослинництва / Г.I. Подпрятов, Л.Ф. Скалеиька, А.М. Сеньков. - К. : Вища освіта, 2004. - 272 с.

3. Глеваський B.I. Технологія зберігання та переробки продукції рослинництва: методичні вказівки до виконання практичних робіт для студентів агробіотехнологічного факультету за кредитно-модульною системою навчання / В.І. Глеваський. - Біла Церква, 2014. - 68 с.

4. Cereals and cereal products - Determination of moisture content - Reference method : ISO 712:2009.

5. Iвах P. Систематизація методів вимірювання вологості сипких матеріалів / P.Івах, М.Дорожовець, I.Питель // Вимірювальна техніка і метрологія. - 2003. - № 62. - С. 97-101.

6. Бенедицький В.Б. Радіохвильовий метод вимірювання вологості матеріалів / В.Б. Бенедицький, Л.Ю. Козак, А.В. Яворська // Вісник ЖДТУ. - № 4 (59). - Житомир, 2011. - С. 32-41.

7. Бенедищький В.Б. Визначення вологості зерна за затуханням НВЧ потужності / В.Б. Бенедицький, Л.Ю. Козак, В.Ф. Манойлов // Вісник ЖДТУ. - № 2 (61). - Житомир, 2012. - С. 59-66.

8. Patent US2828623 Method for rapid testing moisture content of agricultural products / Lloyd D. Benedict. - United States Patent Office ; Application December 14, 1953 ; Serial № 397, 864.

9. Кухлинг Х. Справочник по физике / Х.Кухлинг. - Пер. с нем. - 2-е изд. - М. : Мир, 1985. - 520 с.

10. Амелина М.А. Программа схемотехнического моделирования Мicro-Сар 8 / М.А. Амелина, С.А. Амелин.М. : Горячая линия - Телеком, 2007. - 464 с.

\section{References:}

1. Lisovskii, V.V. (2005), Teoriya i praktika sverkhvysokochastotnogo kontrolya vlazhnosti sel'skokhozyaistvennykh materialov, BGATU, Minsk, 292 p. 
2. Podprjatov, G.I., Skalec'ka, L.F. and Sen'kov, A.M. (2004), Tehnologija zberigannja i pererobky produkcii' roslynnyctva, Vyshha osvita, K., 272 p.

3. Glevas'kyj, V.I. (2014), Tehnologija zberigannja ta pererobky produkcii' roslynnyctva: metodychni vkazivky do vykonannja praktychnyh robit dlja studentiv agrobiotehnologichnogo fakul'tetu za kredytno-modul'noju systemoju navchannja, Bila Cerkva, $68 \mathrm{p}$.

4. ISO 712:2009 Cereals and cereal products - Determination of moisture content-Reference method.

5. Ivah, R., Dorozhovec', M. and Pytel', I. (2003), «Systematyzacija metodiv vymirjuvannja vologosti sypkyh materialiv», Vymirjuval'na tehnika i metrologija, No. 62, pp. 97-101.

6. Benedyc'kyj, V.B., Kozak, L.Ju. and Javors'ka, A.V. (2011), «Radiohvyl'ovyj metod vymirjuvannja vologosti materialiv», Visnyk ZhDTU, No. 4 (59), pp. 32-41.

7. Benedyc'kyj, V.B., Kozak, L.Ju. and Manojlov, V.F. (2012), «Vyznachennja vologosti zerna za zatuhannjam NVCh potuzhnosti», Visnyk ZhDTU, No. 2 (61), pp. 59-66.

8. Benedict, Lloyd D. (1953), Method for rapid testing moisture content of agricultural products, United States Patent Office, Patent US2828623, Application December 14, 1953, Serial No. 397,864.

9. Kukhling, Kh. (1985), Spravochnik po fizike, translation from German, 2nd ed., Mir, M., 520 p.

10. Amelina, M.A. and Amelin, S.A. (2007), Programma skhemotekhnicheskogo modelirovaniya Micro-Cap 8, Goryachaya liniya - Telekom, M., 464 p.

Бенедицький Василь Борисович - старший викладач кафедри біомедичної інженерії та телекомунікацій Державного університету «Житомирська політехніка».

http://orcid.org/0000-0003-1623-1594.

Наукові інтереси:

- моделювання роботи органів людини;

- обробка та передача медичних даних.

E-mail: vslbened@gmail.com.

Коренівська Оксана Леонідівна - кандидат технічних наук, доцент кафедри біомедичної інженерії та телекомунікацій Державного університету «Житомирська політехніка».

http://orcid.org/0000-0002-3735-7690.

Наукові інтереси:

- побудова медичної апаратури;

- апаратура підтримки життедіяльності;

- дослідження роботи серця.

E-mail: o.l.korenivska@gmail.com.

Морозов Дмитро Сергійович - старший викладач кафедри біомедичної інженерії та телекомунікацій Державного університету «Житомирська політехніка».

https://orcid.org/0000-0002-0807-590X.

Наукові інтереси:

- мережеві технології;

- SDN, SDR.

E-mail: morozovds@ztu.edu.ua. 